\title{
Manajemen Konflik Pemerintah Kota Bogor Antara Forum Muslim Bogor Dengan Masyarakat Tionghoa (Studi Kasus: Perayaan Cap Go Meh 2019)
}

\section{Deliya Gustiani}

Program Studi Ilmu Pemerintahan, Universitas Sultan Ageng Tirtayasa

deliyag22@gmail.com

\author{
E-ISSN 2721-0642 \\ Article Info \\ Recieved: \\ August 112021 \\ Revised: \\ November 12021 \\ Accepted: \\ December 52021 \\ Doi Number \\ https://doi.org/10.37950/ijd.v3i3.113
}

\begin{abstract}
This study describes the conflict management carried out by the Bogor City Government over the conflicts that occurred between the Forum Muslim Bogor and the Chinese Community. In this conflict, it was found that there was intolerance that occurred in the people of Bogor City ahead of the Cap Go Meh celebration in 2019. Where the case of intolerance was carried out by issuing a circular issued by the Forum Muslim Bogor through social media. The letter was circulated very widely which contained an appeal to the Bogor City Government not to facilitate the Cap Go Meh/Bogor Street Festival celebration and called for the Muslim community not to participate in the event because it was considered to damage the faith. In this study, the focus will be on conflict resolution efforts carried out by the Bogor City Government using the theory of Conflict Management and Critical System Heuristics. The research method used is descriptive qualitative research method. Therefore, this study will look at how the conflict resolution carried out by the Bogor City Government towards the conflict.
\end{abstract}

Keywords: conflict resolution, bogor city government, cap go meh. 


\section{Abstrak}

Penelitian ini menjelaskan mengenai manajemen konflik yang dilakukan oleh Pemerintah Kota Bogor atas konflik yang terjadi antara Forum Muslim Bogor dengan Masyarakat Tionghoa. Dalam konflik ini ditemukan adanya intoleransi yang terjadi dimasyarakat Kota Bogor menjelang perayaan Cap Go Meh tahun 2019. Dimana kasus intoleransi tersebut dilakukan dengan cara mengeluarkan surat edaran yang dilakukan oleh Forum Muslim Bogor melalui media sosial. Surat tersebut beredar sangat luas yang mana berisikan mengenai seruan kepada Pemerintah Kota Bogor agar tidak memfasilitasi Perayaan Cap Go Meh/Bogor Street Festival dan menyerukan agar masyarakat muslim tidak berpartisipasi dalam acara tersebut karena dinilai dapat merusak akidah. Dalam penelitian ini akan lebih fokus terhadap upaya resolusi konflik yang dilakukan oleh Pemeritah Kota Bogor dengan menggunakan teori Manajemen Konflik dan Critical System Heuristic. Adapun metode penelitian yang digunakan adalah metode penelitian deskriptif kualitatif. Penelitian ini akan melihat bagaimana resolusi konflik yang dilakukan Pemerintah Kota Bogor terhadap konflik tersebut.

Kata Kunci: resolusi konflik, pemerintah kota bogor, cap go meh.

\section{Pendahuluan}

Bogor adalah salah satu kota budaya yang dikenal dengan keanekaragaam budayanya sejak zaman dulu. Di Kota Bogor terdapat Vihara yang sangat dimuliakan dan dijaga oleh Masyarakat Tionghoa sampai saat ini. Vihara ini terletak di Jl. Perniagaan yang saat ini dikenal dengan Jalan Suryakencana No. 1. Lokasi ini sangat berdekatan dengan Kebun Raya Bogor, dan juga berdekatan dengan lokasi perdagangan yang menjadi pusat perekonomian masyarakat Kota Bogor. Vihara tersebut saat ini dikenal dengan Vihara Dhanagun (Ho Tek Bio). Vihara ini menempati bangunan cagar budaya nasional yang terdapat di Kota Bogor, dan merupakan aset dari Dinas Purbakala Kota Bogor.

\section{Gambar 1}

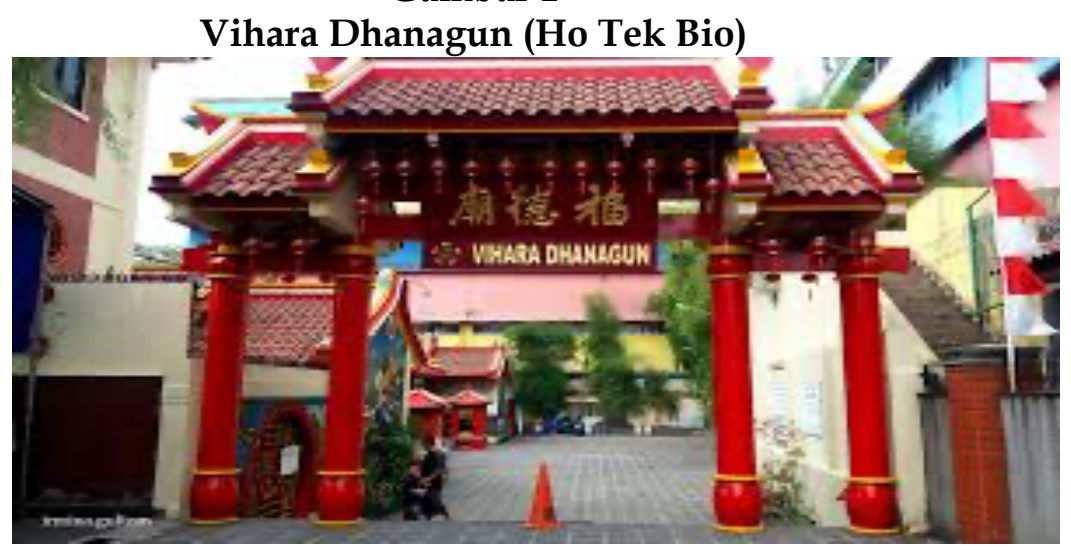

Sumber: (disparbud.jabarprov.go.id) 
Vihara ini pertama kali dibangun pada abad ke-18 oleh masyarakat Tionghoa Kota Bogor. Umur dari Vihara Dhanagun ini lebih dari 300 tahun, lebih tua dibandingkan Istana Bogor dan Kebun Raya Bogor yang letaknya berada sangat dekat dengan Vihara Dhanagun. Seiring dengan berjalannya waktu, Vihara Dhanagun ini mulai kehilangan ciri khas karena pembangunan kota dan pusat perbelanjaan yang ada disekitaran Vihara. Namun pada saat kepengurusan Yayasan Dhanagun, Vihara ini kembali dibangun dan diprakarsai sebagai cagar budaya yang saat ini menjadi budaya yang sangat berharga dan tidak ternilai bagi masyarakat Kota Bogor. Maka dari itu Vihara Dhanagun terus dijaga dan dilestarikan.

Bagi para pemerhati budaya dapat melihat fenomena dimana Vihara Dhanagun ini dapat memberikan rezeki kepada masyarakat Kota Bogor, khususnya kepada masyarakat yang berada disekitaran Vihara. Hal ini disebabkan karena lokasi dari Vihara tersebut yang terletak dipusat perdagangan yang terus berkembang. Selain itu, lokasi tempat Vihara ini dikenal sebagai tempat yang kental akan kebudayaannya. Terdapat banyak sekali ciri khas dari masyarakat Kota Bogor, mulai dari bangunan sampai dengan makanan tradisional khas Kota Bogor yang dapat ditemui dengan mudah disana. Masyarakat Kota Bogor sangat menjunjung tinggi persatuan dan kesatuan. Serta dapat hidup berdampingan dengan rukun tanpa membedakan identitasnya, seperti ras dan agamanya.

Intoleransi sendiri merupakan kondisi dimana sekelompok masyarakat, baik itu dalam hal agama ataupun non-agama yang secara spesifik menolak untuk melakukan toleransi terhadap apa yang dilakukan oleh suatu kelompok lainnya. Dalam hal beragama sendiri, intoleransi yang terjadi bisa berupa penolakan melakukan toleransi terhadap kegiatan ibadah atau kegiatan lainnya yang berlandaskan kepercayaan atau agama yang dianut oleh suatu kelompok masyarakat.

Sikap intolerasi yang terjadi di Indonesia ini terjadi karena adanya dorongan eksternal maupun internal. Salah satu faktor yang mempengaruhi terjadinya sikap intoleransi pada Masyarakat Indonesia ialah pengalaman pribadi, pendidikan, media massa, dan juga kebudayaan. Faktor lainnya yang dapat menmpengaruhi terjadinya kasus intoleransi ialah faktor sosial, ekonomi, politik. Hal inilah yang menjadi pemicu meningkatnya ujaran kebencian yang terjadi pada masyarakat

Maraknya kasus intoleransi dalam kehidupan berbangsa dan beragama mengakibatkan dampak yang sangat serius dalam keberlangsungan hidup karena mengakibatkan sikap yang tidak saling menghargai antar kelompok, tidak adanya prinsip keadilan, kesetaraan dan kesamaan. Sehingga sering sekali terjadi perpecahan dalam kehidupan berbangsa dan negara. Tidak sedikit pula masyarakat indonesia yang mengecam keras atas aksi intoleransi, salah satunya kekerasan agama yang dilakukan oleh kelompok mayoritas kepada kelompok minoritas

Berdasarkan penelitian yang dilakukan oleh Setara Institute, dalam kurun waktu 5 tahun (2014-2019) Jawa Barat merupakan daerah yang sangat sering terjadi kasus intoleransi dalam kebebasan beragama. Hal ini dipicu karena banyaknya aktoraktor lokal yang melakukan persekusi terhadap kelompok minoritas secara terus menerus. Merujuk pada riset yang sudah dilakukan oleh Setara Institute, terdapat 629 kasus intoleransi kebebasan beragama yang terjadi di Jawa Barat. Dalam kurun waktu 
5 tahun (2014-2019) total kasus mencapai 162 pelanggaran. Jumlah kasus yang terjadi di Jawa Barat selama 5 tahun ini lebih tinggi dibandingkan dengan DKI Jakarta yang berjumlah 113 kasus dan Jawa Timur dengan 98 kasus pelanggaran.

Tingginya kasus intoleransi yang terjadi di Jawa Barat menjadi latar belakang yang sangat penting dalam penelitian kali ini. Karena hal ini sangat bersinggungan dengan kasus yang sedang diteliti. Selain karena Jawa Barat merupakan provinsi dengan kasus intoleransi terbanyak, alasan utama yang menjadikan peneliti melakukan penelitian pada kasus ini dikarenakan ini merupakan kasus intoleransi beragama terbesar yang ada di Kota Bogor sendiri.

Kasus ini terjadi pada tahun 2019, kasus pelanggaran kebebasan beragama ini ialah pelarangan penyelenggaraan kebudayaan etnis yaitu Perayaan Cap Go Meh yang dilakukan oleh masyarakat Tionghoa Kota Bogor. Kasus ini diawali dengan penolakan yang dilakukan oleh Forum Muslim Bogor dengan mengeluarkan surat terbuka yang ditunjukan langsung kepada Walikota Bogor. Surat terbuka yang dilakukan oleh Forum Muslim Bogor ini pun beredar di media sosial dan sangat menuai kontroversi dikalangan masyarakat Kota Bogor. Karena hal ini dinilai telah merusak nilai keberagaman agama yang sudah dijunjung tinggi di Kota Bogor.

Dengan adanya surat edaran yang dikeluarkan oleh Forum Muslim Bogor dalam rangka pelarangan umat muslim untuk terlibat dalam acara Cap Go Meh 2019 menjadi cikal bakal terjadinya manajemen konflik yang terjadi antara Forum Muslim Bogor dengan Masyarakat Tionghoa. Pemerintah Kota Bogor hadir sebagai negara yang mewakili setiap masyarakat Kota Bogor tanpa terkecuali, selain itu Pemerintah Kota Bogorpun menjadi penengah akan konflik tersebut dan juga menjadi pihak yang bertanggung jawab akan penyelesaian dari konflik yang terjadi.

\section{Kerangka Teori \\ Manajemen Konflik}

Teori Manajemen Konflik dijadikan sebagai pisau analisa oleh peneliti, dalam penelitian kali ini. Manajemen konflik menurut Minnery (1980) adalah proses rasional yang memiliki sifat interaktif, yang mana proses tersebut terjadi secara terus menerus dan mengalami proses penyempurnaan sampai akhirnya dapat mencapai model yang representatif. Manajemen konflik juga, menjadi salah satu aksi dari reaksi antara pelaku dengan pihak eksternal disalah satu konflik. Selain itu, manajemen konflik termasuk kepada pendekatan yang berorientasi kepada proses yang akan mengarahkannya pada bentuk komunikasi. Komunikasi tersebut dapat berupa tingkah laku dari pelaku ataupun pihak ekternal lainnya. Manajemen konflik juga menggambarkan bagaimana mereka dapat mempengaruhi kepentingan dan juga interpretasi yang dimiliki.

Fisher, dkk (2001) menjelaskan istilah transformasi konflik dengan menggambarkannya secara keseluruhan: Pencegahan Konflik, Penyelesaian Konflik, Pengelolaan Konflik, Resolusi Konflik, Transformasi Konflik

Dari tahapan-tahapan tersebut menjadi kesatuan yang tidak dapat terlepas dan harus dilakukan untuk mengelola konflik yang sedang terjadi. Dalam penelitian kali ini akan lebih fokus lagi terhadap tahapan resolusi konflik. 
Resolusi konflik sendiri merupakan proses pada pemecahan masalah yang dilakukan dengan komperatif dan efektif. Selain itu, resolusi konflik juga sering diartikan sebagai kerangka kerja intelektual guna memahami atas apa yang sedang terjadi dalam konflik tersebut dan juga mulai memikirkan bagaimana nantinya intervensi akan dilakukan. Intervensi yang dimaksud tentunya harus menggunakan pengetahuan khusus mengenai pihak yang terlibat dalam konflik, konteks sosial, orientasi konflik, norma sosial, dll. Dalam resolusi konflik ini sangat berkaitan erat dengan proses yang cukup kooperatif, dimana pembingkaian ulang konflik menjadi proses paling utama dalam proses ini. Karena masalah atau konflik bersama harus diselesaikan dengan upayaa kerjasama, yang artimya akan ada pihak-pihak yang bekerjasama dalam menyelesaikan konflik tersebut.

Menurut Surjawanto (2012) terdapat beberapa rangkaian proses pada resolusi konflik yaitu: Negosiasi, Mediasi, dan Proses Mengambil Keputusan dengan konsensu yang bersifat kolektif.

Setiap pihak ketiga pada tahapan resolusi konflik harus memiliki kemampuan sebagai juru damai, karena pihak ketiga harus menjadi pendengar yang aktif, memiliki kemampuan untuk menangani konflik, mampu membaca situasi serta kondisi yang sedang terjadi, memahami berbagai perspektif terhadap kasus yang sedang terjadi, sampai dengan memiliki kemampuan untuk negosiasi maupun mediasi untuk memecahkan permasalahan yang sedang terjadi dengan seadil mungkin tanpa memihak kepada salah satu pihak.

\section{Critical System Heuristics}

Critical System Heuristics merupakan suatu kerangka atas pertanyaan dari suatu program mengenai apa yang seharusnya menerima dan juga sumber dari legitimasi dan siapa yang seharusnya menerima manfaat dari apa yang sedang dituju. Menurut Werner Ulrich dan Martin Reynolds Critical System Heuristics merupakan suatu pendekatan yang dapat digunakan untuk membatasi, mempertimbangkan atas batas dari seseorang maupun kelompok terhadap sistem yang relevan dari situasi yang memprihatinkan. Critical System Heuristics juga dapat melakukan evaluasi mengenai tujuan yang mana sistem yang sudah menentukan tujuan diawal dan fokusnya akan terletak pada evaluasi sarana untuk mencapai tujuan tersebut menjadi subjek dalma penyelidikan.

\section{Gambar 2 Triangulasi Sistemik}

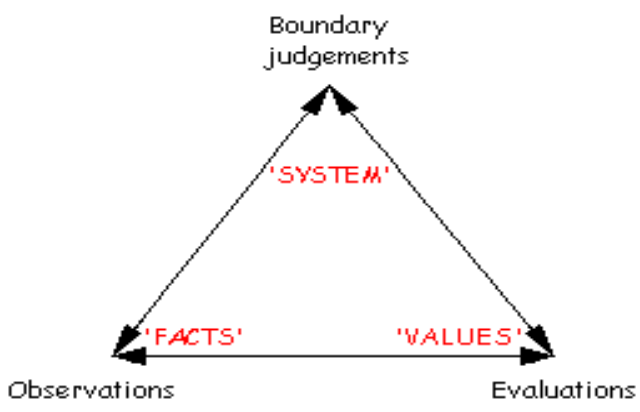

Sumber: (www.wulrich.com) 
Dalam Critical System Heuristic terdapat juga istilah boundary triangel atau systemic triangulation (triangulasi sistemik). Triangulasi sistemik merupkan proses reflektif dari penerapan "segitiga abadi" secara sistematis pada tugas kritik batas. Triangulasi sistematis ini hadir sebagai metodologis baru, dimana ia memperlisa konsep konvensional dengan mempertimbangkan temuan dan kesimpulan yang tidak hanya dalam sudut pandang observasi ganda tetapi melihat juga bagaimana penilaian fakta yang mengandalkan metode penelitian, teori, dan basis data yang berbeda, tetapi melihat juga bagaimana etika yang berbeda dan juga penilaian nilai untuk masalah yang relevan dan sistem referensi. Dengan gagasan triangulasi sistematik ini, menawarkan analogi guna memahami keterampilan inti yang kondusif untuk kritik batas sistematis, serta sikap atau etika profesional kritis.

Intensionalitas manusia adalah salah satu konstitusi dari arti perbaikan dalam perencanaan sosial, yang menjadi dasar atas kategori ditujukan pada orang-orang terutama, dibandingkan dengan masalah sosial material ataupun ruang dan waktu. Walaupun jenis dari penilaian ini masih sangat relevan.

Mengenai kritik batas sistematis, setiap pertanyaan yang ada perlu dijawab dengan baik dengan metode yang ada. Tidak ada jawaban yang pasti, namun dalam batas batas akan selalu dipertimbangkan atas setiap jawaban yang diberikan. Dengan adanya perubahan nilai batas, dapat memungkinkan untuk mengungkap keberpihakan atau selektifitas atas sistem perhatian yang diasumsikan dari berbagai pendapat atau perspektif, sehingga asumsi fakta atau asumsi nilai dapat diidentifikasikan tanpa harus menilainya dengan ilusi objek.

Teori critical system heuristic ini dinilai sangat relevan pada penelitian kali ini, dimana teori ini dapat membantu peneliti dalam berpikir kritis. Terlebih lagi dengan menggabungkannya dengan teori manajemen konflik. Dimana dalam critical system heuristic terdapat trianguasi sistemik yang menggambarkan ide dan proses kritis batas, agar peniliti dapat lebih fokus terhadap konflik yang sedang diteliti dan bagaimana cara untuk mengatasi dan menyelesaikan konflik tersebut. Dapat dikatakan critical system heuristic ini digunakan sebagai cara berpikir dalam menyeselasikan konflik (manajemen konflik).

\section{Metode Penelitian}

Penelitian ini menggunakan metode kualitatif deskriptif. Metode kualitatif sendiri merupakan pemaparan fakta-fakta untuk menjawab rumusan masalah dari penelitian. Penelitian deskriptif menitik beratkan pada suasana alamiah yang memaparkan situasi atau peristiwa. (Rakhmat,199:45). Penelitian ini menggunakan metode penelitian deskriptif-kualitatif yang bertempat di Kota Bogor. Penelitian deskriptif-kualitatif bertujuan untuk menggambarkan, meringkaskan berbagai kondisi dan situasi yang terjadi di Kota Bogor terutama dalam perayaan Cap Go Meh 2019. Dengan demikian format kualitatif deskiptif ini sangat cocok untuk digunakan dalam meneliti bagaimana Manajemen Konflik yang dilakukan oleh Pemerintah Kota Bogor dalam kasus perayaan Cap Go Meh 2019. 
Volume 3, Issue 3, December 2021

http://hk-publishing.id/ijd-demos

\section{Hasil dan Diskusi}

Kronologis Terjadinya Konflik (Penolakan Adanya Perayaan Cap Go Meh Tahun 2019)

Perayaan Cap Go Meh di Kota Bogor sudah mulai dikenal lebih dari 100 tahun, namun perayaan ini sempat hilang dan mulai muncul kembali pada tahun 2003. Perayaan Cap Go Meh ini tentu saja tidak terlepas dari bangsa Tionghoa yang datang ke Kota Bogor pada zaman penjajahan. Biasanya Perayaan ini dilakukan disekitaran Jalan Suryakencana, yang mana kawasan tersebut merupakan kawasan pecinaan yang ada di Kota Bogor. Pada tahun 2008 mulai muncul gagasan mengenai acara street festival dan perayaan Cap Go Meh menjadi festival di Kota Bogor. Dari tahun ketahun perayaan Cap Go Meh di Kota Bogor terus berkembang. Puncak perkembangan perayaan Cap Go Meh ini ialah pada tahun 2012 dimana perayaan Cap Go Meh resmi menjadi Bogor Street Festival yang diresmikan langsung oleh Gubernur Jawa Barat pada saat itu

Keberhasilan perayaan Cap Go Meh atau Bogor Street Festival tentunya tidak terlepas dari dukungan dan hasil kolaboratif dari semua pihak yang terlibat didalamnya. Acara Bogor Street Festival ini dibagi menjadi dua bagian, yaitu pawai barongsai, liong, joli dan kesenian tradisonal yang akan berjalan mulai dari Jalan Suryakencana menuju Jalan Siliwangi dan kembali lagi ke Vihara Dhanagun yang berada di Jalan Suryakencana. Kemudian acara selanjutnya ialah penampilan seni budaya dipanggung pertunjukan yang berada didekat Vihara Dhanagun.

Selama persiapan Cap Go Meh atau Bogor Street Festival bekerja sama dengan berbagai pihak dari semua kalangan, mulai dari TNI, Polri, Mahasiswa sampai dengan para seniman dan budayawan yang ada di Jawa Barat khususnya Jabodetabek. Pihak penyelenggara yang terlibat tidak saja masyarakat Tionghoa saja, melainkan seluruh umat beragama lainnya ikut serta dalam memeriahkan acara ini.

Menjelang perayaan Cap Go Meh pada tahun 2019, beredar surat edaran yang dikeluarkan oleh Forum Muslim Bogor mengenai penolakan terkait perayaan Cap Go Meh. Isi dari surat tersebut ialah seruan bagi seluruh masyarakat muslim yang ada di Kota Bogor maupun Kabupaten Bogor untuk berpartisipasi dalam perayaan Cap Go Meh 2019. Selain itu dalam surat tersebut tertulis bahwasannya pemerintah dilarang untuk memfasilitasi dan juga meminta Walikota untuk tidak mengarahkan para ASN untuk menghadiri apalagi sampai terlibat dalam acara Cap Go Meh 2019. Surat larangan perayaan Cap Go Meh ini beredar sangat luas dimedia sosial seperti Facebook, Twitter, Instagram dan WhatsApp. Tentu saja dengan beredar luasnya surat larangan tersebut banyak diketahui oleh masyarakat khususnya masyarakat Kota Bogor.

Selain mengeluarkan surat larangan mengenai Cap Go Meh disosial media, Forum Muslim Bogor juga mendatangi Kantor MUI Kota Bogor untuk menyampaikan secara langsung terkait surat tersebut. Kedatangan Forum Muslim Bogor pada saat itu langsung diterima oleh Kedataangan Forum Muslim Bogor tersebut diterima oleh Ketua MUI Kota Bogor dan Komisi Fatwa. Dalam pertemuan tersebut terjadi dialog yang dilakukan oleh Forum Muslim Bogor dengan pihak MUI. 


\section{Resolusi Konflik Yang Dilakukan Oleh Pemerintah Kota Bogor}

Pada dasarnya resolusi konflik memerlukan penyelesaian dari masalah yang ada. Dalam konteks konflik sendiri resolusi konflik merupakan upaya yang dilakukan untuk menemukan solusi yang dapat diterima oleh seluruh pihak yang terlibat konflik. Dari resolusi konflik tersebut akan dicari mana solusi yang dapat memenuhi seluruh kepentingan yang terlibat pada konflik tersebut.

Dalih dari Forum Muslim Bogor ialah dengan keikut sertaan masyarakat muslim dalam acara Cap Go Meh dapat merusak keimanan dan dapat menimbulkan keresahan bagi masyarakat muslim. Sedangkan Perayaan Cap Go Meh atau Bogor Street Festival ini sebelumnya hanya menampilkan kebudayaan khas Tionghoa saja, kemudian dipadukan dengan kebudayaan Sunda dan mengusung tema Nusantara. Dengan kata lain, Perayaan Cap Go Meh atau Bogor Street Festival ini bukanlah suatu ritual melainkan kebudayaan yang sudah ada sejak puluhan sampai ratusan tahun yang lalu. Dan acara Cap Go Meh ini menjadi ajang pemersatu bangsa.

Dalam menanggapi pernyataan yang dikeluarkan oleh Forum Muslim Bogor, pihak MUI melakukan diskusi dengan Forum Muslim Bogor ketika Forum tersebut datang ke Kantor MUI. Ketua MUI Kota Bogor menjelaskan bahwasannya Perayaan Cap Go Meh tersebut bukanlah perayaan ibadah yang dilakukan oleh Masyarakat Tionghoa, melainkan pesta rakyat atau suatu kebudayaan yang perlu didukung dan diapresiasi sebagai bentuk kerukunan antar umat beragama di Kota Bogor. Karena masyarakat Kota Bogor sangat menjunjung tinggi keberagaman yang ada. Tidak ada akidah yang dirusak apabila masyarakat muslim ikut serta dalam Bogor Street Festival. Pihak MUI tentu saja mendukung secara penuh adanya perayaan ini. MUI Kota Bogor sendiri bahkan ikut serta dalam pembukaan acara Cap Go Meh, yang mana acara Bogor Street Festival ini dibuka dengan doa bersama yang dilakukan oleh para pemuka agama.

Manajemen konflik adalah salah satu langkah yang diambil oleh pelaku atau pihak eksternal dengan tujuan untuk mengarahkan konflik yang sedang terjadi pada proses penyelesaian konflik secara mufakat. Manajemen Konflik dalam konflik penolakan perayaan Cap Go Meh yang dikeluarkan oleh Forum Muslim Bogor ini dilakukan oleh pihak ketiga, yaitu MUI Kota Bogor dan Pemerintah Kota Bogor.

Resolusi Konflik sendiri merupakan proses pada pemecahan masalah yang dilakukan dengan komperatif dan efektif. Dalam resolusi konflik ini sangat berkaitan erat dengan proses yang cukup kooperatif, dimana pembingkaian ulang konflik menjadi proses paling utama dalam proses ini. Karena masalah atau konflik bersama harus diselesaikan dengan upayaa kerjasama, yang artimya akan ada pihak-pihak yang bekerjasama dalam menyelesaikan konflik tersebut. Dimana pihak yang terlibat dalam penyelesaian konflik dalam kasus penolakan perayaan Cap Go Meh ini ialah MUI Kota Bogor dan Pemerintah Kota Bogor.

Menurut Surjawanto (2012) menyebutkan terdapat beberapa rangkaian dalam resolusi konflik, yaitu: 


\section{Negosiasi}

Negosiasi bertujuan untuk mencari titik terang dalam penyelesaian konflik, tanpa adanya aksi kekerasan yang terjadi. Pada proses ini akan terjadi tawar-menawar yang nantinya akan menghasilkan keputusan dasar dalam pembentukan peraturan antara pihak-pihak yang terlibat konflik. Dalam proses negosiasi juga terdapat proses komunikasi dari pihak-pihak yang terlibat konflik, yang mana pihak-pihak tersebut berupaya untuk saling mempengaruhi dan mendapatkan apa yang diinginkan. Pada tahapan negosiasi ini dilakukan oleh MUI Kota Bogor, pada saat Forum Muslim Bogor mendatangi kantor MUI untuk menyampaikan pernyataan dan memberikan surat edaran untuk menolak dilibatkannya masyarakat muslim dan juga menghimbau agar pemerintah tidak memfasilitasi perayaan Cap Go Meh atau Bogor Street Festival.

\section{Mediasi}

Proses mediasi ini dilakukan dengan cara bermusyawarah untuk menyelesaikan konflik. Proses dilakukan atas dasar keinginan dari pihak yang terlibat konflik tanpa adanya paksaan. Dalam proses mediasi memiliki keutungan yaitu, penyelesaiannya bersifat formal dan diselesaikan secara langsung dengan pihak yang terlibat konflik. Selain itu, dengan proses mediasi ini hubungan antara pihak-pihak yang terlibat konflik akan tetap terjalin dengan baik. Hal ini disebabkan karena dasar proses mediasi adalah musyawarah dengan bantuan pihak mediator sebagai penengah yang sifatnya netral atau tidak berpihak hanya kepada satu pihak saja. Dalam proses mediasi merupakan salah satu cara untuk intervensi dalam konflik yang sedang terjadi, sehingga pihak mediator harus mendapatkan kepercayaan dari para pihak yang terlibat konflik.

Dalam kasus konflik penolakan yang dilakukan oleh Forum Muslim Bogor terhadap perayaan Cap Go Meh atau Bogor Street Festival pada tahun 2019 tidak ada proses mediasi. Hal ini disebabkan karena permasalahan atau konflik yang terjadi dapat diselesaikan pada tahapan negosiasi.

\section{Pengambilan Keputusan}

Proses pengambilan keputusan ini dilakukan untuk menghindari perdebatan, maka dari itu persoalan atau permasalahan yang dirundingkan harus berdasarkan landasan yang kuat agar dapat diterima oleh seluruh pihak. Proses pengambilan keputusan yang dilakukan oleh Pemerintah Kota Bogor sudah berdasarkan landasan yang kuat, hal ini dapat dilihat dari Misi yang ke-6 Kota Bogor tahun 2015-2019, yaitu: "Mengokohkan peran moral agama dan kemanusiaan untuk mewujudkan masyarakat madani". Peran moral agama dan kemanusiaan bukan hanya menjadi hal yang tumbuh dan mempengaruhi pada ranah individual saja, tetapi dapat menjadi penggerak bagi pembangunan kota. Kota akan menjadi terus berkembang, dimana masyarakat akan hidup rukun dan damai.

Dengan adanya perayaan Cap Go Meh atau Bogor Street Festival ini diharapkan dapat menjadi citra baik bagi Kota Bogor dan juga sebagai bukti bahwasannya Kota Bogor merupakan kota yang beragam mulai dari ras, suku, dan agama. Yang mana 
didalamnya masyarakat dapat hidup dengan rukun, damai, dan saling menghormati antar umat beragama.

\section{Kesimpulan}

Pemerintah Kota Bogor melakukan penanganan konflik dengan bekerjasama. Pemerintah Kota Bogor melakukan kerjasama dengan beberapa pihak terkait seperti, MUI Kota Bogor, Para pemuka agama, sampai dengan TNI-POLRI. Berdasarkan teori yang dikemukakan oleh Surjawanto (2012), Pemerintah Kota Bogor melakukan dua rangkaian resolusi konflik yaitu:

Negosiasi; dimana pada proses ini pihak yang terlibat ialah Forum Muslim Bogor dan Pihak MUI Kota Bogor. Proses ini dilaksanakan pada saat Forum Muslim Bogor mendatangi kantor MUI Kota Bogor. Negosiasi berhasil dilakukan oleh pihak MUI, dan juga berhasil meyakinkan Forum Muslim Bogor bahwasannya Perayaan Cap Go Meh atau Bogor Street Festival merupakan perayaan kebudayaan bukan sekedar perayaan keagamaan saja. Yang mana hal ini harus terus dijaga dan dilestarikan guna merawat kebudayaan serta sikap toleransi yang ada di Kota Bogor.

Pengambilan Keputusan; pada proses pengambilan keputusan dilakukan guna menghindari perdebatan. Dalam proses ini Pemerintah Kota Bogor mengambil keputusan berdasarkan landasan yang kuat sehingga dapat diterima oleh seluruh pihak termasuk Forum Muslim Bogor. Pemerintah Kota Bogor mengumpulkan para pemuka agama, Forum Kerukunan Umat Beragama, TNI-POLRI serta memberitahukan kepada seluruh masyarakat Kota Bogor bahwasannya perayaan Cap Go Meh atau Bogor Street Fstival tidak dapat merubah akidah agama manapun, dan peryaan ini merupakan pesta rakyat. Pengambilan keputusan ini sudah sesuai dengan Misi yang ke-6 Kota Bogor tahun 2015-2019, yaitu: "Mengokohkan peran moral agama dan kemanusiaan untuk mewujudkan masyarakat madani".

Keberhasilan resolusi konflik yang dilakukan Pemerintah Kota Bogor menjadikan Bogor Street Festival menjadi lebih meriah, dihadiri langsung oleh Gubernur Jawa Barat, Menteri Pariwisata dan Ekonomi Kreatif. Selain itu pada tahun berikutnya Perayaan Cap Go Meh atau Bogor Street Festival masuk kedalam top 100 Calender of Event dari Kementrian Pariwisata dan Ekonomi Kreatif.

\section{Tentang Penulis}

Deliya Gustiani adalah mahasiswa Ilmu Pemerintahan, FISIP, Untirta. salah satu kajian yang diminati adalah Hak Minoritas.

\section{Ucapan Terimakasih}

Terima Kasih Kepada semua yang membantu penelitian ini dan bimbingannya terhadap penelitian ini. 


\section{Referensi}

Aisyah. 2014. Konflik Sosial Dalam Hubungan Antar Umat Beragama. Jurnal Dakwah Tabligh, Volume 15 No.2

Apandi, 2020. Pendekatan Resolusi Konflik Dalam Upaya Pencegahan Konflik Regional Pada Era Digitalisasi. Jurnal Inovasi Ilmu Sosial dan Politik, Vol. 2 No. 1

Astri, Herlina. 2011. Penyelesaian Konflik Sosial Melalui Pendekatan Kearifan Lokal. Jurnal Aspirasi, Vol. 2 No. 2

Ariefana, Pebriansyah. 2019. Kontroversi Larangan Cap Go Meh di Bogor

https://wwww.suara.com/news/2019/01/30/060500/kontroversi-larangan-cap-go-meh-di-bogor

Diakses pada Kamis, 19 Maret 2020, pukul 16.00 WIB

Arjani, Dwi. 2019. Cerita Warga Kota Bogor Tetap Khusyuk Saat Ada Edaran Tolak Imlek.

Budiarjo, Miriam. 1982. Dasar-dasar Ilmu Politik. Jakarta: Gramedia.

Caroline. (2016) Pilkada Setentak, Eksklusi Partai Politik, dan Masa DepanPolitik Representasi. The POLITICS: Jurnal Magister Ilmu Politik Universitas Hasanuddin Vol. 2 No. 1

Darmawan, Ikhsan (2015). Menggugat (Praktik) Representasi Politik.

Djani, Luky. (2017) Representasi Politik: Relasi Imaginer Konstituen dan Politikus?

Douglas, Mary. 1966. Purity And Danger "An Analysis Of The Concepts Of Pollution And Taboo". USA: Routledge.

Ekawaty, Esti.(2014). Dari Representasi Politik Formal Ke Representasi Politik NonElektoral. Depok:Pusakapol FISIP UI

Fisher, Simon, dkk. 2001. Mengelola Konflik : Untuk Bertindak, Ahli Bahasa S. N. Kartikasari, dkk. Jakarta : The British Counsil, Indonesia.

https://metro.tempo.co/read/1172481/cerita-warga-kota-bogor-tetap-khusyuk-saat-ada-edarantolak-imlek Diakses pada Kamis, 19 Maret 2020, pukul 16.15 WIB Bunga, Halida. 2019. Setara: 2.400 Insiden Pelanggaran Kebebasan Beragama

https:/ / nasional.tempo.co/read/1271038/setara-ada-2-400-insiden-pelanggarankebebasan-beragama Diakses Pada Kamis, 7 Januari 2021, pukul 15.50

Disparbud Jawa Barat. 2012. Vihara Mahacetya Dhanagun

http:/ / www.disparbud.jabarprov.go.id/wisata/dest-det.php?id=135\&lang=id

Diakses pada Rabu,18 Maret 2020, pukul 15:00 WIB Krisniandi, 2020. Setara: Ada 846 Kejadian Pelanggaran Kebebasan Beragama di Era Jokowi.

https://nasional.kompas.com/read/2020/01/07/16031091/setara-ada-846-kejadian-pelanggarankebebasan-beragama-di-era-jokowi Diakses Pada Kamis, 7 Januari 2021, pukul 16.00 
Ika, Aprilia. 2019. Beredar Surat Penolakan Imlek dan Cap Go Meh, MUI dan Pemkot Bogor Buka Suara.https://bogor.kompas.com/read/2019/01/30/07095491/beredar-suratpenolakan-perayaan-imlek-dan-cap-go-meh-mui-dan-pemkot-bogor Diakses pada Kamis, 19 Maret 2020, pukul 15.30 WIB

Kementerian Koordinator Bidang Politik, Hukum, dan Keamanan. 2016. Tantangan Peningkatan Kualitas Partisipasi dan Representasi. Jakarta: Kementerian Koordinator Bidang Politik, Hukum, dan Keamanan

Khatimah, Husnul. 2019. Heboh Beredar Seruan Omas Tolak Bogor Street Fest CGM https://www.ayobogor.com/read/2019/01/28/2424/ayobogor.com Diakses pada Kamis, 19 Maret 2020, pukul 15.00 WIB

Nasution. (2014) Demokrasi dan Politik Minoritas Di Indonesia

Putra, Arie. 2014. Menuju Demokrasi Bermakna: Persoalan-persoalan Perbaikan Representasi Politik di Indonesia. Jakarta: Demos.

Reily, Ben. 2000. Demokrasi dan Konflik yang Mengakar : Sejumlah Pilihan Negosiator. Jakarta: International IDEA

Ronald. H. Chilcote. 2003. Teori Perbandingan Politik. Jakarta: Raja Pers.

Setiawan, Rahmat. (2018) Subaltern, Politik Etis, dan Hegemoni dalam Perspektif Spivak. V ol. VI No . 1Poetika : Jurnal Ilmu Sastra

Simon, Roger. 2004. Gagasan-gagasan Politik Gramsci. Yogyakarta: Pustaka Pelajar

Subono. 2012 Demokrasi Tanpa Representasi: Masalah dan Pilihan Demokrasi di Empat Daerah. Jakarta:Demos.

Soeseno, N. 2013. Representasi Politik. Perkembangan dari Ajektiva ke Teori. Depok: Puskapol.

Ulrich, Werner. 2014. A Primer To Critical Systems Heuristics For Action Researchers. Centre for Systems Studies: University Of Hull.

Zainuddin, Denny. 2016. "Analisis Penaganan Konflik Antar Organisasi Kemasyarakatan Di Sumatera Utara (Medan) Dan Jawa Tengah (Purwakarta)" .Jurnal Hak Asasi Manusia Volume 7 No.1 